\title{
An Exploration of the Relationship between Listening Strategy Use and Listening Comprehension of Undergraduate EFL Students
}

\section{Sibel Tosun ${ }^{1}$}

\section{* Correspondence: \\ sibeltosun@outlook.com \\ 1.School of Foreign Languages, Firat \\ University, Turkey}

Received: 19 February 2021

Revision: 4 April 2021

Accepted: 2 May 2021

Published online: 20 June 2021

\begin{abstract}
Listening skill, which gains momentum with the increase of digitalized resources in the globalizing world, puts language learners who can make use of listening strategies one step ahead. This paper sought to investigate the listening strategy use of EFL undergraduate students in relation to their foreign language listening performance. $157 \mathrm{EFL}$ students at a state university, who were aged between 18-23 participated in the study. This descriptive study employed a quantitative approach. Nakatani's (2006) Oral Communication Strategy Inventory (OCSI) was used for data collection purposes. A listening test was also administrated to the participants in order to measure their listening comprehension. The statistical analyses revealed that the participants mostly employed negotiation for meaning strategy followed by scanning and getting the gist strategies. The results also indicated that only getting the gist strategy was a significant predictor of L2 listening performance. A statistically significant difference between high and low-achieving L2 listeners was also found on negotiation for meaning, getting the gist, scanning, and nonverbal strategies.
\end{abstract}

Keywords: EFL, listening comprehension, listening proficiency, listening $\underline{\text { strategies, }} \underline{\text { OCSI }}$ 


\section{Introduction}

Similar to first language acquisition, learners of a second language depend primarily on language input to explore through language, make meaning, and learn about linguistic features before taking a further step to produce it. It is now beyond discussion that learners need to be exposed to a certain amount of linguistically rich input to acquire a language (Gass \& Selinker, 2001), and along with reading, listening provides a valuable means for this kind of exposure.

With the advancements in technology and the abundance of digital sources and online materials, spoken input has become easier to reach. The role of listening and listening comprehension, thus, has reinforced its place in language learning and teaching. Nevertheless, despite its growing popularity and use, listening is a challenging skill for learners (Golchi, 2012). Listening in English may be overwhelming particularly in settings such as Turkey due to the conventional instruction learners receive in primary education, which is substantially based on grammar instruction with some focus on reading and vocabulary while little emphasis on listening skills is given (Ulum, 2015). As a natural consequence, poor listening habits are likely to result in misunderstanding, communication breakdowns, and stress in the end (Graham, 2006).

Two reasons for the inability to eliminate these factors are unawareness of efficient listening strategies and ineffective teaching methodologies (Vandergrift, 2007; Young, 1992). For that reason, the knowledge of listening strategies might get students to overcome these challenges (Kök, 2017; Oxford, 1990) and help them develop into better listeners (Bidabadi \& Yamat, 2011; Vandergrift, 2003, 2007). However, before simply proceeding with strategy instruction, specifying the strategies already being utilized by learners should be the first step in order to determine their needs and select appropriate strategies (Oxford, 1990, p. 204).

Since listening is a complex mental process (Vandergrift, 1999), which comprises various underlying operations, it is critically important to identify what learners do during listening and how they comprehend listening texts to better understand the process (O'Malley et al., 1989). Furthermore, identifying the strategies utilized by language learners provides means of determining and classifying them and serves to distinguish the characteristics of good language learners as well as to inform educational studies that attempt to teach those strategies (Chamot, 2005). Thus, it is a matter of paramount importance to define the strategies learners already put to use and the ones need to be instilled according to their listening comprehension levels.

\subsection{Statement of the Problem}

Although listening comprehension is given more attention in the Turkish context recently, it is still not assessed as a component of high stake language examinations such as university entrance exam and YDS (Foreign Language Exam). The washback effect of this causes stakeholders to give less attention to listening skills and strategies while leaving an underexplored area not only in Turkey but in similar contexts, where listening has not gained ground as much as other skills. A closer look at the literature on a broader context brings out a number of gaps and shortcomings on the exploration of listening strategies and listening comprehension. The connection between listening proficiency and listening strategies was investigated in the literature (Eslahkonha \& Mall-Amiri, 2014; Kassem, 2015; Kaya, 2017; Kök 2017; Yulisa, 2018), and the results demonstrated that high proficient learners employed more strategies than less proficient learners.

However, much uncertainty remains about the predictive ability of listening strategies on listening comprehension. Thus, the novelty in the present study lies in its attempt to find out if any of listening strategies could predict successful listening comprehension. Identifying such a relationship could inform teachers about which strategies could play a role in better listening task performance, and leads them to design an effective listening strategy instruction.

\subsection{Research Questions}

Three research questions were established in the present study:

1. What are the listening strategies employed by Turkish undergraduate EFL students studying at a state university?

2. Which of the listening strategy subscales, if any, are the predictors of Turkish EFL students' listening comprehension scores?

3. Is there any difference between high-achieving and low-achieving listeners in terms of their reported use of listening strategies? 


\subsection{Research Hypotheses}

Aligned with the research questions specified above, two hypotheses were generated based on the relevant literature. The hypotheses of the present study are as follows:

1. All five listening strategies could predict success in L2 listening strategies.

2. There is a statistically significant difference between high-achieving and low-achieving listeners in their use of listening strategies.

\section{Review of the Literature}

With the aim of understanding how listening comprehension occurs on a deeper level, researchers have investigated how input is processed through theories of information processing. Among these, Anderson (1995) provided the mostwidely acknowledged model. In this model, successful listening comprehension takes place in three interrelated processes: perception, parsing, and utilization. Perception occurs when a listener focuses on the individual sounds to be stored in the echoic memory, which requires further processing. In the second phase, parsing, the listener attempts to convert the heard utterance into meaningful units. Lastly, at the utilization stage, the listener tries to match the meaning drawn from listening with his/her previous knowledge (p. 358).

This complex process seems to be hard to follow successfully. Therefore, a considerable number of learners experience challenges while comprehending listening texts. Some of the problems involve unknown words, fast speech, connected speech, distractions, memory loads, varying intonational patterns, and interpretation (Renukadevi, 2014; Siegel, 2018; Su, 2007; Vandergrift, 1999). Second language learners are obliged to direct their attention to these issues and various processes in order to be proficient in listening (Siegel, 2018), and utilization of listening strategies bears utmost importance in the process of decoding, understanding, and interpreting the message while listening (Gonen, 2009).

Learner strategies are broadly defined as "specific actions taken by the learner to make learning easier, faster, more enjoyable, more self-directed, and more transferable to new situations" (Oxford, 1990, p.8). Regarding the taxonomy of listening strategies, there are varying views and classifications. Two commonly accepted and researched classifications belong to Goh (1998) and O'Malley and Chamot (1990). While Goh's (1998) classification involved cognitive and metacognitive strategies, O'Malley and Chamot (1990) classified listening strategies under the categories of metacognitive, cognitive, and socio-affective strategies. Accordingly, metacognitive strategies are defined as the strategies that aid comprehension such as planning, monitoring, evaluating, and problem-solving. Cognitive strategies are the ones in charge of manipulation and transformation while doing a task. Socio-affective strategies, on the other hand, are those that are related to "social-mediating activity and transacting with others" (p. 126).

A particular emphasis needs to be placed on metacognition and metacognitive awareness on account of their being a concept that constitutes the theoretical framework of this study. Metacognition is the capability of being conscious of one's mental processes (Flavell, 1976). Metacognitive knowledge helps learners perform better by encoding given elements and represents the assumptions in a problem context (Davidson \& Sternberg, 1998). Learners with metacognitive awareness potentially have the knowledge and regulatory skills to manage cognition, and thus it is deemed necessary to regulate strategies efficiently (Schraw, 1998). As listening comprehension requires such ability, metacognitive knowledge plays a key role in the process of listening. Empirical research has attested that equipping learners with metacognitive strategies enhances their listening comprehension (Bozorgian, 2014; Vandergrift \& Tafaghodtari, 2010). Understanding in what ways acquiring these strategies assists learners could give a full picture of the phenomenon.

The benefits of strategy use have been articulated in a plethora of publications from various perspectives. For instance, Oxford (1990) emphasizes that learning strategies direct learners into being more self-conscious and self-directed, which facilitates involvement in the learning process. Echoing Oxford (1990), Liu (2008) notes that implementation of a strategic approach could lead enhancement of autonomy and self-regulation in education, through which students make their own choices, determine their own goals, and track their progression. When learners are conscious of listening strategies and have the capability of applying them, they can properly grasp and utilize language input (Vandergrift, 1998). Considering that learners commonly face problems in understanding input and experience affective issues, they can minimize these challenges when they are introduced to listening strategies (Namaziandost 
et al., 2020). Once learners are aware of the merits of strategies they possess, they can develop autonomy that will assist them in selecting relevant strategies to their needs (Berne, 2004).

Listening strategy use was investigated in the literature through a number of inventories/questionnaires such as the Metacognitive Awareness Listening Questionnaire (MALQ) (Vandergrift et al., 2006), Oral Communication Strategy Inventory (OCSI) (Nakatani, 2006), and Strategy Inventory for Language Learning (SILL) (Oxford, 1990). Among them, OCSI, which was originally designed to elicit communication strategies of EFL students, comprises of two parts: strategies to cope with speaking problems and strategies to cope with listening problems. The listening component, which is the focus of this study, has seven sub-categories: negotiation for meaning whilst listening, scanning, getting the gist, non-verbal, less active listener, and lastly word-oriented strategies.

According to Nakatani (2006), negotiation for meaning whilst listening strategies are made use for negotiating meaning during listening to keep the talk going. Fluency-maintaining strategies are utilized for attending to the "fluency of conversational flow" (p. 156). Scanning strategies require concentrating on particular features such as verbs and nouns, which are deemed important. Getting the gist strategies involve utilizing background information and paying attention to context and general meaning rather than specific details. Non-verbal strategies whilst listening are the strategies of attending to the nonverbal features such as body language and eye contact in order to promote comprehension. Less active listener strategies such as translating in mind and relying heavily on familiar words are used when faced with difficulties in understanding. Lastly, word-oriented strategies could be characterized as depending on individual words to get a general understanding (p. 156). The strategy inventory was found to be correlated with SILL (Oxford, 1990) and is widely used with the aim of exploring learner strategies.

Studies on the exploration of listening strategy use reported different strategies as being the most and least frequent. From the most frequent to the least, negotiation for meaning whilst listening, non-verbal strategies whilst listening, and getting the gist strategies (Metcalfe \& Noom-Ura, 2013); negotiation for meaning, non-verbal and word-oriented strategies (Nakatani, 2006); getting the gist, compensation, and word-oriented strategies (Chiang, 2011); getting the gist, non-verbal, fluency-maintaining, and negotiation for meaning (Pawlak, 2015) were reported as the most frequently used listening strategies. Unlike the above cited research, Chairat (2017) found that scanning was the most frequent strategy followed by non-verbal strategies and negotiation for meaning whilst listening strategies respectively. On the other hand, Ounis (2016) reported that learners employed non-verbal strategies the most, preceding negotiation for meaning and getting the gist strategies, although scanning strategies are reported to be the least used strategies.

Apart from the investigation of learner strategies, their relation with proficiency/comprehension has also been an area of interest. Richards (2008) asserts that learners' language proficiency and communication skills are in connection with their strategy usage. Indicating a positive relationship, Oxford (1990) maintains that "good language learners" show variety and sophistication in their use of strategies. This kind of association also applies within the context of listening. It has been evidenced that learners who are proficient in listening are able to use several metacognitive, cognitive, and socio-affective strategies while listening (Cohen, 1990).

Elaborating on those strategies, O'Malley and Chamot (1990) characterize effective and ineffective listeners with their strategy use, noting that effective listeners maintain concentration, use their world knowledge and experience, get the gist, focus on details, and refocus during listening. They also mark that ineffective listeners focus on isolated words, try to translate in mind, and cannot refocus and infer meaning (pp. 131-132). Goh (2002) confirms the existence of those features, adding that proficient listeners make use of cognitive and metacognitive listening strategies in a more comprehensive manner, utilize linguistic cues, and use their background knowledge while less proficient ones use a smaller number of strategies, and their attention is usually diverted by unfamiliar vocabulary.

The use of listening strategies with different proficiency groups has been investigated by several studies (Bidabadi \& Yamat, 2011; Chao, 1996; Goh, 2002; Liu, 2008; Ounis, 2016; Sönmez \& Durmaz, 2017; Vandergrift, 2003; Wu, 2007). The research on this line mostly suggests that high proficient listeners make use of listening strategies more frequently and show more variety in usage compared to less proficient listeners (Goh, 2002; Liu, 2008; Vandergrift, 2003). The correlation between listening strategy use and listening comprehension was also dealt with in a number of studies, and a positive correlation was found between the two variables (Bidabadi \& Yamat, 2011; Eslahkonha \& Mall-Amiri, 2014; Kassem, 2015; Kaya, 2017; Kök 2017; Yulisa, 2018). 
However, these studies employed various kinds of listening proficiency/performance tests, e.g., Oxford Placement Test in Bidabadi and Yamat (2011); Longman TOEFL in Kassem (2015); IELTS in Kök (2017) and TOEFL in Yulisa (2018). Thus, generalizing the findings of those studies becomes problematic (Berne, 2004). For this reason, despite a considerable number of research attempts, the field can still be motivating enough for further research especially for the Turkish context, in which no research was conducted to explore the predictive ability of listening strategies on listening comprehension along with the strategy differences between successful and less successful listeners to the best of the researcher's knowledge. Listening strategy use and its relation to listening performance, thus, deserve further in-depth investigations.

\section{Methodology}

\subsection{Participants and Setting}

The present study was conducted in the School of Foreign Languages at a state university in Turkey. In the institution, students receive general English instruction composed of four skills to receive $30 \%$ and English-medium instruction in their respective fields. In one academic year, which includes four modules, listening is given as an integrated skill in the first three modules, and all the visas and final exams include listening comprehension tests. Learners are given listening and speaking and reading and writing skills separately in the fourth module.

Regarding the participants, a total of 157 students from two departments (mechanical and software engineering) with an age range of 18 and 23 participated in the study. The participants were placed at elementary level classes at the beginning of the year after a proficiency test, and they were all studying at pre-intermediate level at the time of the study. Convenient sampling was employed since data were collected from the learners available at that moment (Creswell, 2015).

\subsection{Research Design}

The study utilized quantitative approach with a correlational design in order to explore and identify listening strategy use of participants and its relationship with their listening comprehension levels. A correlational design allows for the investigation of relationship between variables and the prediction of scores, but doesn't attempt to explain or identify causal relationship (Cresswell, 2015). Among the types of correlational design, the prediction design was adopted with the aim of investigating whether any listening strategies could predict listening comprehension success.

\subsection{Instruments}

Two instruments were used for data collection in the present study: A listening comprehension test and a Listening Strategy Inventory. The listening comprehension test was administrated to test students' listening comprehension in English. The test consisted of four listening texts and twenty questions in total. In parts A and B, the students were supposed to hear conversations and answer ten multiple-choice questions. In part $\mathrm{C}$ and $\mathrm{D}$, learners were asked to listen to monologues and answer ten multiple-choice questions. The questions required listening for gist and listening for specific information. Listening texts took about 14 minutes in total. The test was prepared by the researcher and later checked by the examination committee in the institution for construct, content and face validity, and languagelevel appropriacy. It was later piloted with 25 students for internal consistency, and the Cronbach alpha coefficient was found .82 .

To determine the listening strategies of the participants, the listening component of the Oral Communication Strategy Inventory (OCSI), which was developed by Nakatani (2006) and adapted by İrgin (2011) was also used for data collection. After İrgin (2011) translated OCSI into Turkish, the inventory was subjected to factor analysis, and a fivefactor scale was constructed. Although the initial questionnaire included 7 factors, in the factor-analysed version by İrgin (2011), five factors were found: negotiation for meaning while listening strategies $(N=6)$, getting the gist strategies $(N=6)$, scanning strategies $(N=4)$, nonverbal strategies $(N=3)$, and word-oriented strategies $(N=2)$. İrgin (2011) has reported that the Listening Strategy Inventory has a good internal consistency, with a Cronbach alpha coefficient of .84. In the current study, the Cronbach alpha coefficient was calculated as .75. Through 21 items scale, the participants were asked to rate each statement on a 5-point rating scale ranging from: $1=$ "never applies to me", 2 = "rarely applies to me", 3 = "sometimes applies to me", 4 = "often applies to me", 5 = "always applies to me." The scale was used in Turkish since all the participants were native speakers of Turkish. Along with the Listening Strategy Inventory, some demographic information regarding students' age and gender were collected as well.

\subsection{Data Collection}


The study was conducted in spring term of 2018-2019 academic year. The instruments were administrated in two sessions because of time limitations and administrative issues. Firstly, the listening comprehension test was conducted during regular instructional time. All participants took the test in the same session. They were given the Listening Strategy Inventory in the following session. The participants took about 10 minutes to complete the inventory. Before the data were collected, the participants were informed that the data collected would be used for research purposes, the study was on a voluntary basis, and they could withdraw any time they like.

\subsection{Data Analysis}

A statistical package was used to conduct a descriptive analysis of the questionnaire. In order to answer the first research question, which explores the strategy use of the participants, descriptive analysis was conducted. While interpreting the mean scores, Oxford's (1990) scoring system for 5-point Likert scale was used. The scores 1.0 - 2.4 indicate low strategy use, while the scores 2.5 - 3.4 indicate medium strategy use. The scores ranging between 3.5 5 , on the other hand refers to high strategy use. Next, to determine how much of the listening comprehension variance is accounted for by the listening questionnaire factors, the test scores and questionnaire data were run through regression analysis. Lastly, for the differences between high-achieving and low-achieving listeners in terms of their reported use of listening strategies, a one-way between-groups multivariate analysis of variance was also performed.

\section{Findings}

\subsection{Listening Strategy Use of the Participants}

The data were first investigated to find out the overall listening strategy use of the participants. The results from the analysis of the frequencies revealed that the participants had high awareness of the listening strategies $(N=156, M=$ 3.92). The data were further analyzed to find out the listening strategy tendencies of the participants under five strategy components. The results are presented in Table 1.

Table 1. Descriptive statistics for listening strategy use

\begin{tabular}{llllll}
\hline Strategies & $N$ & Minimum & Maximum & $M$ & $S D$ \\
\hline & & & & & \\
\hline Negotiation for meaning & 157 & 1.67 & 5.00 & 3.97 & .63 \\
Getting the gist & 157 & 1.67 & 5.00 & 3.62 & .63 \\
Scanning & 157 & 1.50 & 5.00 & 3.89 & .61 \\
Nonverbal & 157 & 1.00 & 5.00 & 3.41 & .79 \\
Word-oriented & 157 & 2.00 & 5.00 & 3.47 & .69 \\
\hline
\end{tabular}

Descriptive statistics in Table 1 indicate that negotiation for meaning strategy held the highest mean value among the strategies $(M=3.97, S D=.63)$, which means that the learners employed negotiation for meaning strategies the most. Scanning strategies were found to be the second most used strategy by the learners $(M=3.89, S D=.61)$ followed by getting the gist strategies $(M=3.62, S D=.61)$, word-oriented strategies $(M=3.47, S D=.69)$, and non-verbal strategies $(M=3.41, S D=.79)$.

\subsection{Predictive Ability of Listening Strategy Subscales on Listening Comprehension Scores}

Multiple linear regression was computed to determine if the listening strategy factors (negotiation for meaning, getting the gist, scanning, nonverbal and word-oriented) could predict participants' listening comprehension performance. Preliminary analyses were conducted to ensure no violation of the assumptions of normality, linearity, multicollinearity, and homoscedasticity. Cook's distances were all well below 1.00, indicating that there were no cases that had an undue influence on the regression coefficients. The results of multiple regression analysis regarding the determined predicting variables are given in Table 2. 
Table 2. Multiple regression results for the predicting ability of listening strategies on listening performance

\begin{tabular}{lcccccc}
\hline Predictors & \multirow{2}{*}{$*$} & $t$ & Sig. & \multicolumn{3}{c}{ Correlations } \\
\cline { 6 - 8 } & & & & Zero order & Partial & Part \\
\hline Negotiation for meaning & .054 & .67 & .503 & .095 & .055 & .052 \\
Getting the gist & .206 & 2.4 & .015 & .252 & .195 & .070 \\
Scanning & .059 & .67 & .499 & .163 & .055 & .053 \\
Nonverbal & .076 & .89 & .374 & .173 & .0 .72 & .070 \\
Word-oriented & .028 & .35 & .727 & .058 & .028 & .027 \\
\hline
\end{tabular}

Table 2 shows that the overall regression model was statistically significant, $F(5,151)=2.69, p<0.05$. The $\mathrm{R} 2$ value of 0.28 indicated that $22 \%$ of the variance in listening proficiency was predicted by five listening strategy subscales. Out of the five Listening Strategy Inventory subscales, only getting the gist strategy measure was significant $(\beta=.20$, $p<.05)$ explaining $3 \%$ of the total variance. The other four subscales; negotiation for meaning $(\beta=.054, p=.504)$; nonverbal $(\beta=.076, p=.37)$; scanning $(\beta=.059, p=.49)$; word-oriented $(\beta=.028, p=.72)$ fell short of statistical difference. The results indicate that although participants who could use listening strategies tended to get higher scores in the listening test, only getting the gist strategies could uniquely predict their listening comprehension success.

\subsection{The Differences Between High-Achieving and Low-Achieving Listeners in Their Reported Use of Listening Strategies.}

A one-way between-groups multivariate analysis of variance was performed to investigate the differences between high achieving and low achieving listeners in their reported use of listening strategies. Five categories of listening strategies, namely negotiation for meaning, getting the gist, scanning, nonverbal and word-oriented strategies were used as dependent variables. The independent variable was listening comprehension scores. The participants were first clustered into two groups (through SPSS) based on the scores they received from the listening comprehension test and they were tagged as high achievers and low achievers.

Preliminary assumptions were checked for normality, linearity, univariate and multivariate outliers, homogeneity of variance-covariance matrices, and multicollinearity, and serious violations were not noted. Descriptive statistics for the mean scores for each group are given in Table 3.

Table 3. Descriptive statistics for listening strategies by listening achievement

\begin{tabular}{lllllll}
\hline Strategies & \multicolumn{2}{l}{ High achievers } & \multicolumn{5}{c}{ Low achievers } \\
\hline & $N$ & $M$ & $S D$ & $N$ & $M$ & $S D$ \\
\hline Negotiation for meaning & 116 & 4.10 & .58 & 40 & 3.57 & .60 \\
Getting the gist & 116 & 3.84 & .49 & 40 & 3.02 & .51 \\
Scanning & 116 & 4.10 & .46 & 40 & 3.27 & .58 \\
Nonverbal & 116 & 3.59 & .79 & 40 & 2.85 & .48 \\
Word-oriented & 116 & 3.51 & .79 & 40 & 3.28 & .48 \\
\hline
\end{tabular}

Descriptive statistics, which are displayed in Table 3, indicate higher strategy employment of high achievers in all strategy components (negotiation for meaning $(M=4.10, S D=.58)$, getting the gist $(M=3.84, S D=.49)$, scanning $(M=4.10, S D=.46)$, nonverbal $(M=3.59, S D=.79)$, and word-oriented strategies $(M=3.51, S D=.79)$ compared to low achievers (negotiation for meaning $(M=3.57, S D=.60)$, getting the gist $(M=3.02, S D=.51)$, scanning $(M=$ $3.27, S D=.58)$, nonverbal $(M=2.85, S D=.48)$, and word-oriented strategies $(M=3.28, S D=.48)$. 
In order to determine if the differences between the two groups (high-achievers and low-achievers) were statistically significant, MANOVA was computed. Multivariate analysis for listening strategies by successful groups is presented in table 4.

Table 4. A one-way between-groups multivariate analysis of variance for listening strategies by listening achievement

\begin{tabular}{lllllll}
\hline Strategies & Sum of squares & $d f$ & Mean Square & $f$ & $p$ & Partial eta \\
\hline Negotiation for meaning & 8.48 & 1 & 8.48 & 24.59 & .000 & .138 \\
Getting the gist & 19.79 & 1 & 19.788 & 79.084 & .000 & .339 \\
Scanning & 20.31 & 1 & 20.308 & 82.360 & .000 & .348 \\
Nonverbal & 16.63 & 1 & 16.628 & 31.617 & .000 & .170 \\
Word-oriented & 1.57 & 1 & 1.570 & 3.409 & .067 & .022 \\
\hline
\end{tabular}

Table 4 reveals a significant difference between high-achievers and low-achievers on the combined variables $F(5$, $150)=40.08, p=.000$; Wilks' Lambda $=.42$; partial eta squared $=.57$. When the results for the dependent variables were considered separately using a Bonferroni adjusted alpha of .017, four types of strategies reached statistical significance including negotiation for meaning $F(1,8.48)=24.59, p=.000$, partial eta squared $=.13$, getting the gist $F(1,19.78)=79.08, p=.000$, partial eta squared $=.33$, scanning $F(1,20.31)=82.36, p=.000$, partial eta squared $=$ .34 , and nonverbal strategies $F(1,16.63)=31.61, p=.000$, partial eta squared $=.17$. In other words, high achieving students differ significantly from their low achieving peers in their strategy use across four listening strategies.

\section{Discussion}

This study sought to investigate the listening strategy use of the undergraduate EFL learners and its relationship with their listening comprehension scores. The findings demonstrated high listening strategy use. When analyzed under sub-components, the results revealed that the learners employ negotiation for meaning strategies the most, followed by scanning, getting the gist, word-oriented, and nonverbal strategies. The relatively fewer use of non-verbal strategies could be attributed to negligence of nonverbal communication in language teaching and learning (Surkamp, 2014; Sutiyatna, 2018). While learners focus on improving their listening comprehension through one-way listening materials such as books, CDs, and podcasts, they do not probably get the chance to enhance their non-verbal skills and strategies. This finding concurs with previous studies (Metcalfe \& Noom-Ura, 2013; Nakatani, 2006), wherein negotiation for meaning was found the most frequently employed strategy by learners. This result, on the other hand, is contrary to those of Chairat (2017), Pawlak (2015), and Ounis (2016), wherein scanning, getting the gist, and nonverbal strategies were reported, respectively, as the most employed strategies.

The second question in the study attempted to determine whether listening strategy factors contributed to the listening performance of the participants. It was found that listening strategies altogether could predict success in listening. However, when analyzed individually, only getting the gist strategy was found to be a strong predictor for the outcome measure of L2 listening performance. It can be implied from the results that the learners who employ getting the gist strategies could get higher scores in listening tests. Considering that the half of the questions in the listening comprehension test measures getting the gist ability, it is understandable that the participants who could employ this strategy tend to get higher scores. The relationship between listening comprehension success and getting the gist strategy is no surprise since successful learners are better at grasping the overall meaning of a listening text, while less skilled ones usually focus on individual words (Chamot \& Kupper, 1989; Chao, 1997, as cited in Berne, 2004).

Thus, employing getting the gist strategy in the process of listening seems to lead a better task performance, and it stands out as a strategy to focus on in order to enhance listening. The results somewhat differ from Liu and Thondhlana (2015), who found that all the strategy components were predictors of listening performance. While discussing the variance in the findings, it is important to note that task types may have had an influence on learners' listening comprehension performance. A recent study by Taheri and Hedayat Zade (2018) revealed that learners show better 
performance in selection questions compared to completion questions. Since only multiple choice questions were directed to students in order to test their listening comprehension, the results regarding the predictive ability of listening strategies may have shown contrasting results. Several other factors such as vocabulary load (Yang, 2011) self-esteem (Hayati \& Ostadian, 2008) and anxiety (Ko, 2010; Vogely, 1998) could be expressed as the reasons for such difference. For this reason, they need to be further investigated as potential predictors of listening performance.

With respect to the third research question, which dealt with whether the strategy use was stable across different success groups, a statistically significant difference between high-achievers and low-achievers was found. The groups differed in terms of the strategies they employ. The detailed analyses have revealed that high-achievers outperformed low-achievers in four categories and overall listening strategy use. These results corroborate the findings of a great deal of the previous work (Eslahkonha \& Mall-Amiri, 2014; Kassem, 2015; Kaya, 2017; Kök, 2017; Yulisa, 2018), which indicated higher strategy use of more proficient listeners compared to less proficient ones.

The consistency of the findings across the above cited research might be linked with both social and linguistic sources learners rely on while listening. Considering that learners who could show more variety in their use of strategies resort to their background knowledge, and both interpret and monitor during listening (Vandergirft, 2003), they are more likely to outperform less strategic listeners in listening. Being equipped with such strategies seem to render assistance during listening in enhancing listening comprehension and overcoming the challenges previously stated in the introduction part. This suggests more emphasis on equipping learners with listening strategies to improve their listening skills.

As for the findings regarding the differences between high and low-achieving listeners in listening strategy subcomponents, it was revealed that high and low achievers were different in their use of word-oriented strategies. The finding does not support the work of Ounis (2016) who noted that low proficiency listeners employed wordoriented strategies more than high proficiency listeners. The reason for the lack of difference in the use of wordoriented strategies could be explained by the common use of the strategy in both high and low achievers. That is to say, more proficient listeners could employ both top-down and bottom-up strategies while less proficient ones mostly focus on bottom-up strategies with more focus on isolated words (Liu, 2008). Simply put, low-achieving students may have tended to employ word-oriented strategies at similar levels with high-achievers since they rely too much on bottom-up strategies to comprehend texts neglecting other strategies. This finding may justify Nakatani's (2006) warning about overreliance on individual words because such reliance to decipher general meaning instead of synthesizing and interpreting what is heard could affect comprehension.

\section{Conclusion}

This study set out to explore the use of listening strategies of Turkish undergraduate EFL students and the relationship between their strategy use, its sub-components, and listening performance. An obvious finding to emerge from the analysis was the learners' tendency to use negotiation for meaning and getting the gist strategies the most frequently. Another promising finding of the study was that learners who performed better in listening tests employed more strategies than low-achieving listeners, indicating a demand for strategy instruction for the development of listening comprehension. Besides, although listening strategies in general predicted listening comprehension, when analyzed under sub-components, only getting the gist strategy was a significant predictor of higher listening ability. Taking the findings into consideration, it is hoped that this research will contribute to a deeper understanding of learners' use of listening strategies and their significance in improving listening comprehension of EFL learners.

\subsection{Implications and Limitations}

The findings of this study have some implications for teaching and learning listening skills. This study corroborates that successful listeners employ a wider range of listening strategies compared to less-successful listeners. Thus, the results imply a need for strategy training to enhance listening comprehension of learners. The positive effect of employing listening strategies consciously and effectively has already been noted in numerous studies (Carrier, 2003; Graham et al., 2008; Ozeki, 2000; Vandergrift, 2002, 2003). Although there are doubts about the suitability of strategy instruction for lower-level learners, listening strategy training was found to be effective in improving the listening comprehension of beginner level students (Coşkun, 2010). Further to that, Mareschal (2007) and Vandergrift and Tafaghodtari (2010) argue that low proficiency learners can benefit from strategy instruction more than high proficiency learners. 
Before starting strategy training, regardless of listening proficiency levels of learners, it is best to determine which strategies learners are aware of and which of them they are not in order to plan an effective training program. Instead of forcing learners to have more listening practice even if they cannot succeed, which causes more stress, being conscious of the challenges learners have and developing strategies accordingly seems to be a better alternative for effective learning (Graham, 2006). At this stage, teachers need to adopt a strategy-based instruction, the objective of which is to teach students how to listen and develop "metastrategic awareness" (Mendelsohn, 1995, p.134). This is an arduous task for teachers since their teaching practices are mostly shaped by two factors: assessment requirements and textbook content (Graham, 2017). In this regard, implications for curriculum developers and textbook writers are also presented. Program developers should include more listening strategies and practice in their curricula, going beyond testing students' listening skills with questions that only require selecting the correct answer. Textbook and material writers, on the other hand, could give coverage to listening strategies with appropriate exercises for teachers, who cannot find opportunities to incorporate these into their teaching schedule due to various reasons such as administrative issues and tight schedule.

This paper reported the perceived use of listening strategies by the participants. Therefore, a full discussion of to what extent learners can truly use these strategies lies beyond the scope of this study. With this limitation in mind, a further study with a focus on how these strategies are put to use is suggested. Moreover, due to practical and administrative constraints, listening comprehension test items were limited to twenty questions. For this reason, the use of a more comprehensive listening comprehension test with different item types is recommended for further research.

\section{References}

Anderson, J. R. (1995). Cognitive psychology and its implications. W. H. Freeman and Company.

Berne, J. (2004). Listening comprehension strategies: A review of the literature. Foreign Language Annals, 37(4), 521-531. https://doi.org/10.1111/j.1944-9720.2004.tb02419.x

Bidabadi, F., \& Yamat, H. (2011). The relationship between listening strategies used by Iranian EFL freshman university students and their listening proficiency levels. English Language Teaching, 4(1), 26-32. https://doi.org/10.5539/elt.v4n1p26

Bozorgian, H. (2014). The role of metacognition in the development of EFL learners' listening skill. International Journal of Listening, 28(3), 149-161. doi: 10.1080/10904018.2013.861303

Carrier, K. A. (2003). Improving high school English language learners' second language listening through strategy instruction. Bilingual Research Journal, 27(3), 383-408. https://doi.org/10.1080/15235882.2003.10162600

Chairat, P. (2017). Oral communication strategies used by English major undergraduates during the internship program. Proceeding of the International Conference on Literature, History, Humanities and Interdisciplinary Studies (LHHISS-17), Bangkok (Thailand), July (pp. 11-12).

Chamot, A. U. (2005). The cognitive academic language learning approach (CALLA): an update. In P. A. RichardAmato \& M. A. Snow (Eds.), Academic success for English language learners: Strategies for K-12 mainstream teachers (pp. 87-101). Longman.

Chamot, A. U., \& Küpper, L. (1989). Learning strategies in foreign language instruction. Foreign Language Annals, 22(1), 13-22. https://doi.org/10.1111/j.1944-9720.1989.tb03138.x

Chao, Y. G. (1996). The influence of strategy use on comprehension and recall of authentic English listening texts by Chinese EFL students in Taiwan (Unpublished doctoral dissertation). University of Minnesota.

Chiang, H. P. (2011). University EFL freshman's use of oral communication strategies. Master's thesis, Tunghai University. Tunghai University Institutional Repository.

Cohen, A. D. (1990). Language Learning: Insights for learners, the teacher, and researcher. Newbury House. https://doi.org/10.2307/3586956

Coşkun, A. (2010). The effect of metacognitive strategy training on the listening performance of beginner students. Novitas-Royal, 4(1), 35-50. 
Creswell, J. (2015). Educational research: Planning, conducting, and evaluating quantitative and qualitative research. Pearson.

Davidson, J. E., \& Sternberg, R. J. (1998). Smart problem solving: How metacognition helps. In D. J. Hacker, J. Dunlosky, \& A. C. Graesser (Eds.), Metacognition in educational theory and practice (pp. 47-68). Mahwah, NJ: Lawrence Erlbaum Associates.

Eslakonha, F., \& Mall-Amiri, B. (2014). The correlation between English language listening comprehension ability, and listening strategy use among Iranian TEFL junior university students. International Journal of Language $\begin{array}{lllll}\text { Learning and Applied } \quad \text { Linguistics } & \text { 190-203. }\end{array}$ https://scholar.google.com/citations?hl=en\&user=2nGgA3AAAAAJ\&view_op=list_works\&sortby=pubdate

Flavell, J. H. (1976). Metacognitive aspects of problem solving. In L. B. Resnick (Ed.), The nature of intelligence (pp. 231-236). Erlbaum.

Gass, S. M., \& Selinker, L. (2001). Second language acquisition: An introductory course (2nd ed.). Lawrence Erlbaum Associates.

Goh, C. (1998). How ESL learners with different listening abilities use comprehension strategies and tactics. Language Teaching Research, 2(2), 124-147. https://doi.org/10.1177/136216889800200203

Goh, C. (2002). Teaching listening in the language classroom. SEAMEO Regional Language Centre.

Golchi, M. M. (2012). Listening anxiety and its relationship with listening strategy use and listening comprehension among Iranian IELTS learners. International Journal of English Linguistics, 2(4), 115-128. https://doi.org/10.5539/IJEL.V2N4P115

Gonen, M. (2009). The relationship between FL listening anxiety and FL listening strategies: The case of Turkish EFL learners. In Perlovsky, L. (Ed.), Proceedings of the 5th WSEAS/IASME International Conference on Educational Technologies (EDUTE 09), July 2009 (pp. 44-49). WSEAS Press.

Graham, S. (2006). Listening comprehension: the learners' perspective. System, 34(2), 165-182. https://doi.org/10.1016/j.system.2005.11.001

Graham, S. (2017). Research into practice: Listening strategies in an instructed classroom setting. Language Teaching, 50(1), 107-119. https://doi.org/10.1017/s0261444816000306

Graham, S., Santos, D., \& Vanderplank, R. (2008). Listening comprehension and strategy use: A longitudinal exploration. System, 36(1), 52-68. https://doi.org/10.1016/j.system.2007.11.001

Hayati, A., \& Ostadian, M. (2008). The relationship between self-esteem and listening comprehension of EFL students. Glossa, 3(2), 300-312. https://www.semanticscholar.org/paper/The-Relationship-between-Selfesteem-and-Listening-Hayati-Ostadian/2b28b363d89e155ab77016d49dcffcee270c64ba

İrgin, P. (2011). Listening strategies used by Turkish students learning English as a foreign language: The development of listening strategy inventory. Master's thesis, Mersin University. The Coincil of Higher Education: National Thesis Center.

Kassem, H. M. (2015). The relationship between listening strategies used by egyptian EFL college sophomores and their listening comprehension and self-efficacy. English Language Teaching, 8(2), 153-169. https://doi.org/10.5539/ELT.V8N2P153

Kaya, T. (2017). A follow-up study on listening strategy use and self-efficacy in relation to listening proficiency in EFL. The Economic Review of Toyo University, 42(2), 155-166.

Ko, Y. A. (2010). The effects of pedagogical agents on listening anxiety and listening comprehension in an English as a foreign language context. Doctoral dissertation, Utah State University. Utah State University Libraries.

Kök, İ. (2017). Relationship between listening comprehension strategy use and listening comprehension proficiency. International Journal of Listening, 32(3), 163-179. https://doi.org/10.1080/10904018.2016.1276457 
Liu, H. J. (2008). A study of the interrelationship between listening strategy use, listening proficiency levels, and $\begin{array}{llll}\text { learning } & \text { style. } & \text { RARECLS, } & \text { 8, }\end{array}$ https://research.ncl.ac.uk/media/sites/researchwebsites/arecls/liu_vol5.pdf

Liu, M., \& Thondhlana, J. (2015). A study of Chinese university EFL learners' foreign language listening anxiety, listening strategy use and academic listening performance. Indonesian Journal of English Language Teaching, 10(1), 30-47. https://nottingham-repository.worktribe.com/output/992477

Mareschal, C. (2007). Student perceptions of a self-regulatory approach to second language listening comprehension development. Unpublished doctoral dissertation. University of Ottawa.

Mendelsohn, D. (1995). Applying learning strategies in the second/foreign language listening comprehension lesson. In Mendelsohn, D., Rubin, J. (Eds.), A guide for the teaching of second language listening (pp. 186-221). Dominie Press.

Metcalfe, J., \& Noom-Ura, S. (2013). Communication strategy use of high and low proficiency learners of English at a Thai university. Learn Journal: Language Education and Acquisition Research Network, 6(1), 68-89. https://so04.tci-thaijo.org/index.php/LEARN/article/view/102722

Nakatani, Y. (2006). Developing an oral communication strategy inventory. The Modern Language Journal, 90(2), 151-168. https://doi.org/10.1111/j.1540-4781.2006.00390.x

Namaziandost, E., Imani, A., Sharafi, S., \& Banari, R. (2020). Exploring the relationship between listening strategies used by Iranian EFL senior high school students and their listening comprehension problems. International Journal of Research in English Education (IJREE), 5(1), 36-52. https://doi.org/10.29252/ijree.5.1.36

O’Malley, J. M., \& Chamot, A. U. (1990). Learning strategies in second language acquisition. Cambridge University Press. https://doi.org/10.1017/CBO9781139524490

O’Malley, J. M., Chamot, A. U., \& Kupper, L. (1989). Listening comprehension strategies in second language acquisition. Applied Linguistics, 10(4), 418-437. https://doi.org/10.1093/applin/10.4.418

Ounis, T. (2016). Exploring the use of oral communication strategies by high and low proficiency learners of English: Tunisian EFL students as a case study. International Journal of Humanities and Cultural Studies (IJHCS), 3(1), 1077-1098. https://www.ijhcs.com/index.php/ijhcs/article/view/1410

Oxford, R. (1990). Language learning strategies: What every teacher should know. Newbury House/Harper \& Row.

Ozeki, N. (2000). Listening strategy instruction for female EFL college students in Japan. Unpublished doctoral dissertation. University of Pennsylvania.

Pawlak, M. (2015). Advanced learners' use of communication strategies in spontaneous language performance. In M. Pawlak \& E. Waniek-Klimczak (Eds.), Issues in teaching, learning and testing speaking in a second language (pp. 121-141). Springer. https://doi.org/10.1007/978-3-642-38339-7_8

Renukadevi, D. (2014). The role of listening in language acquisition; the challenges \& strategies in teaching listening. International Journal of Education and Information Studies, 4(1), 59-63. https://www.ripublication.com/ijeisv1n1/ijeisv4n1_13.pdf

Richards, J. C. (2008). Teaching listening and speaking. Cambridge University Press.

Schraw, G. (1998). Promoting general metacognitive awareness. Instructional Science, 26, $113-125$. https://doi.org/10.1023/A:1003044231033

Siegel, J. (2018). Learning listening. In A. Burns \& J. C. Richards (Eds.), The Cambridge guide to learning English as a second language (pp. 195-203). Cambridge University Press.

Sönmez, G., \& Durmaz, B. (2017). Relationship among efficacy, strategy use and proficiency: Case of listening in an EFL classroom. Turkish Online Journal of English Language Teaching (TOJELT), 2(3), 133-150. https://doi.org/10.30998/scope.v2i02.2381 
Su, S. W. (2007). A study of the effects of text type on college student's listening strategy choice while taking listening comprehension test. Master's thesis, National Changhua University of Education. National gigital library of thesis and dissertations in Taiwan. https://hdl.handle.net/11296/9gz659

Surkamp, C. (2014). Non-verbal communication: Why we need it in foreign language teaching and how we can foster it with drama activities. Scenario, 2014(2), 12-27. doi: https://doi.org/10.33178/scenario.8.2.3

Sutiyatno, S. (2018). The effect of teacher's verbal communication and non-verbal communication on students' English achievement. Journal of Language Teaching and Research, 9(2), $430-437$. https://doi.org/10.17507/JLTR.0902.28

Taheri, P., \& Hedayat Zade, M. (2018). The contribution of metacognitive strategies to EFL learners' listening comprehension task types. Teaching English Language, 12(2), 169-198. https://doi.org/10.22132/TEL.2018.82864

Ulum, Ö. G. (2015). Listening: The ignored skill in EFL context. International Journal of Humanities Social Sciences $\begin{array}{llll}\text { and } \quad \text { Education } & \text { (IJHSSE), } & \text { 72-80. }\end{array}$ https://www.researchgate.net/publication/295898572_Listening_The_Ignored_Skill_in_EFL_Context

Vandergrift, L. (1999). Facilitating second language listening comprehension: acquiring successful strategies. ELT Journal, 53(3), 168-176. https://doi.org/10.1093/elt/53.3.168

Vandergrift, L. (2003). Orchestrating strategy use: towards a model of the skilled L2 listener. Language Learning, 53(3), 463- 496. https://dx.doi.org/10.1111/1467-9922.00232

Vandergrift, L. (2007). Recent developments in second and foreign language listening comprehension research. Language Teaching, 40(3), 191-192. https://doi.org/10.1017/s0261444807004338

Vandergrift, L., Goh, C. C., Mareschal, C. J., \& Tafaghodtari, M. H. (2006). The metacognitive awareness listening questionnaire: Development and validation. Language Learning, 56(3), 431-462. https://doi.org/10.1111/j.1467-9922.2006.00373.x

Vandergrift, L., \& Tafaghodtari, M. (2010). Teaching 12 learners how to listen does make a difference: an empirical study. Language Learning, 60(2), 470-497. https://doi.org/10.1111/j.1467-9922.2009.00559.x

Vogely, A. J. (1998). Listening comprehension anxiety: Students' reported sources and solutions. Foreign Language Annals, 31(1), 67-80. https://doi.org/10.1111/j.1944-9720.1998.tb01333.x

Wu, C. H. (2007). A study of listening strategies and difficulties of high-proficiency and low-proficiency English majors in Taiwan-A think-aloud study. Unpublished master's thesis. National Changhua University of Education.

Yang, M. N. (2011). A study on EFL learners' listening comprehension difficulties by using listening diaries. Journal of Chang Gung Institute of Technology, 14(1), 133-147. http://dx.doi.org/10.6192\%2fCGUST.2011.6.14.11

Young, D. J. (1992). Language anxiety from the foreign language specialist's perspective: Interactive with Krashen, Omaggio Hadley, Terrell, and Rubin. Foreign Language Annuals, 25(2), 157-172. https://doi.org/10.1111/j.1944-9720.1992.tb00524.x

Yulisa, D. (2018). Learning to listen: Listening strategies and listening comprehension of Islamic senior high school students. Edukasi: Jurnal Pendidikan dan Pengajaran, 5(1), 22-30. https://doi.org/10.19109/ejpp.v5i1.2046 